\title{
Retraction Note to: Diltiazem may preserve renal tubular integrity after cardiac surgery
}

\author{
Swen N. Piper, MD · Bernhard Kumle, MD · Wolfgang H. Maleck, MD · \\ Arndt-Holger Kiessling, MD · Andreas Lehmann, MD - Kerstin D. Röhm, MD · \\ Stefan W. Suttner, MD · Joachim Boldt, MD
}

Published online: 27 July 2011

(C) Canadian Anesthesiologists' Society 2011

\section{Retraction Note to: Can J Anesth \\ (2003) 50:285-292 \\ DOI 10.1007/BF03017799}

To our readers:

Landesärztekammer Rheinland-Pfalz ("LÄK-RLP”), the State Medical Association of Rheinland-Pfalz, Germany serves as the Institutional Review Board (IRB) for clinical research at Klinikum Ludwigshafen, where Dr. Joachim Boldt's recent research was conducted. The LÄK-RLP has completed a detailed evaluation of the status of IRB approval for research conducted by Dr. Boldt dating back to 1999. The LÄK-RLP has determined to the best of its ability, the status of IRB approval for 101 articles published by Dr. Boldt. There are 88 articles published across a number of journals for which LÄK-RLP was unable to find evidence of IRB approval. The full list of articles appears under a "Joint Statement" which is accessible online at: http://www.springer.com/12630. It is with considerable regret that the Editorial Board hereby retracts the above-referenced article that was published in the Journal in 2003.

The article is being retracted because IRB approval for the research was misrepresented in the published article and such human research without IRB approval is unethical. It does not mean that the research results per se are fraudulent. Klinikum Ludwigshafen has commissioned an investigating committee to systematically assess the veracity of the findings presented in Dr. Boldt's articles against patient and laboratory records.

The online version of the original article can be found under doi:10.1007/BF03017799.
We extend our appreciation to LÄK-RLP for their review of the status of IRB approval for Professor Boldt's research and to the investigating committee at Klinikum Ludwigshafen for their ongoing review of his research findings.

Donald R. Miller, MD, Editor-in-Chief

Canadian Journal of Anesthesia

c/o Department of Anesthesia

The Ottawa Hospital - General Campus

501 Smyth Road, Ottawa, ON K1H 8L6, Canada

e-mail: cja_office@cas.ca

À nos lecteurs:

La Landesärztekammer Rheinland-Pfalz ( «LÄK-RLP»), l'Association médicale du Land de Rhénanie- Palatinat, en Allemagne, sert de Comité d'éthique de la recherche (CER) pour les recherches cliniques réalisées au Klinikum Ludwigshafen, où le professeur Boldt a mené ses recherches récentes. La LÄK-RLP a complété une évaluation détaillée de l'état d'approbation par le CER des recherches menées par le Dr Boldt de 1999 à nos jours. La LÄK-RLP a pu déterminer, dans la mesure de ses compétences, l'état d'approbation par le CER de 101 articles publiés par le Dr Boldt. Au total, 88 articles pour lesquels la LÄK-RLP n'a pas pu trouver de preuve d'approbation par le CER ont été publiés dans plusieurs revues. La liste complète des articles est disponible dans une « Déclaration conjointe » accessible en ligne à l'adresse suivante: http://www.springer.com/ 12630. C'est avec grand regret que le Comité de rédaction rétracte par la présente l'article en référence ci-haut, qui a été publié dans le Journal en 2003.

L'article est rétracté du fait que l'approbation du CER pour la réalisation de cette recherche a été faussement représentée dans l'article publié et qu'une telle recherche chez l'humain n'est pas déontologique sans approbation 
du CER. Toutefois, cela ne signifie pas que les résultats de l'étude sont, en soi, frauduleux. Le Klinikum Ludwigshafen a mandaté un comité d'enquête afin d'évaluer systématiquement la véracité des résultats présentés dans les articles du Dr Boldt par rapport aux dossiers des patients et de laboratoire.

Nous tenons à remercier la LÄK-RLP d'avoir passé en revue l'état d'approbation du CER pour les recherches du professeur Boldt et le comité d'enquête du Klinikum Ludwigshafen pour leur examen actuel de ses résultats de recherche.

Donald R. Miller, MD

Rédacteur en chef 